\title{
Tunasniyoj, a dinosaur tracksite from the Jurassic-Cretaceous boundary of Bolivia
}

\author{
SEbAstián APESTEguía and PABlo A. GALlina \\ CONICET - Fundación de Historia Natural "Félix de Azara" \\ CEBBAD - Universidad Maimónides, Hidalgo 775, $7^{\circ}$ piso, (1405) Ciudad Autónoma de Buenos Aires, Argentina \\ Manuscript received on October 9, 2009; accepted for publication on December 1, 2010
}

\begin{abstract}
Here we report a superbly preserved and profusely represented five-ichnotaxa dinosaur track assemblage near Icla village, $100 \mathrm{~km}$ southeast of Sucre, Bolivia. As preserved in reddish Jurassic-Cretaceous boundary aeolian sandstones, this rich and uncommon assemblage is, additionally, the oldest dinosaur tracksite for Bolivia. Four trackmakers were identified in the area: three quadrupedal and one bipedal, all of them with tracks of around $35 \mathrm{~cm}$ in lenght. One of the quadrupedals is represented by no less than five adult individuals (ichnotaxon A), and four purported juveniles (ichnotaxon B) walking in association. The other two quadrupedals (ichnotaxa C and D) involve four trackways, and the last, the bipedal trackmaker (ichnotaxon E), is represented by one trackway. The five ichnotaxa represented in the "Palmar de Tunasniyoj" could be tentatively assigned to the following trackmakers: Ichnotaxa A and B are assigned to basal stegosaurians; ichnotaxon $\mathrm{C}$ to a basal tyreophoran, perhaps related to the ankylosaur lineage; ichnotaxon $\mathrm{D}$ to the Ankylosauria, and ichnotaxon E to Theropoda. The Tunasniyoj assemblage, the oldest dinosaur tracksite for Bolivia, includes the oldest known evidence assigned to ankylosaurs and stegosaurs for South America.
\end{abstract}

Key words: Bolivia, Chuquisaca, dinosaur prints, ichnology.

\section{INTRODUCTION}

South American dinosaurs became relatively well known along the last decades. However, most of the available knowledge comes from the osteological data preserved in Argentina and Brazil (Bonaparte 1996, Leanza et al. 2004). The ichnological record is still patchy and chronologically redundant, even when it comes from several localities in several countries (e.g., McCrea et al. 2001, Thulborn 1990). Actually, some of the better samples come from latest Cretaceous rocks of Bolivia (Lockley et al. 2002, Leonardi 1994) and Early Cretaceous of Brazil (Leonardi 1994). On the other side, although tracks in the Chacarilla Formation and Baños del Flaco, Chile (e.g., Moreno and Pino 2002, Rubilar-Rogers et al.

Proceedings of the Third Gondwanan Dinosaur Symposium Correspondence to: Sebastián Apesteguía

E-mail: sebapesteguia@gmail.com
2008), show a good abundance and preservation quality of Early Cretaceous dinosaur tracks, they are mainly represented by sauropods, theropods and some large ornithopods (Rubilar-Rogers et al. 2000, 2008). Here we report, in the oldest dinosaur tracksite for Bolivia, the ancientmost southern evidence of tyreophorans that, surprisingly, are represented by three different taxa, including ankylosaurs and the only stegosaur tracks for the Southern Hemisphere.

\section{LOCALITY}

The dinosaur track locality of the Palmer of Tunasniyoj is placed in the Icla Area, $100 \mathrm{~km}$ southeast of Sucre, Chuquisaca Department, Bolivia (Fig. 1). The main site, at $19^{\circ} 31.871^{\prime} \mathrm{S}, 64^{\circ} 45.666^{\prime} \mathrm{W}$, is approximately $6 \mathrm{~km}$ east from the small village of Soroma. 


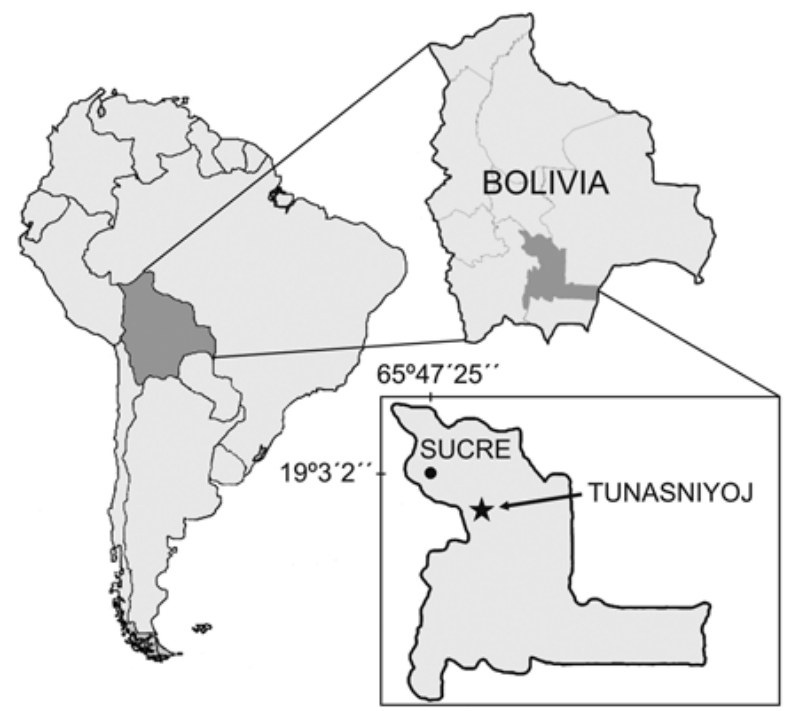

Fig. 1 - Map location of the dinosaur track locality Tunasniyoj, Chuquisaca Department, Bolivia.

\section{TRACKSITE RECORD IN BOLIVIA}

The tracksites in Bolivia are actually abundant, but very poorly known, even for the best represented sites, such as Cal Orck'o, Humaca and Toro Toro (Lockley et al. 2002, Apesteguía et al. 2007, Ríos Cordero 2005). Besides, dinosaur tracks were already found in four of the nine Departments of Bolivia, in the localities of Camargo; Toro Toro and Arampampa, in Potosí (Branisa 1968); Sucre, Nujchu and Maragua in Chuquisaca; and Santivañez and Parotani in Cochabamba, the latter discovered by Leonardi (1981) and lost after a landslide. However, whereas some of these areas preserve rocks that represent coastal to lacustrine deposits related to the Atlantic transgression of the Pacha Sea (e.g., Sucre and El Molino formations), some others show expositions of slightly older rocks (e.g., Toro Toro and Chaunaca formations). This means that most of these tracksites basically preserves the same ichnofauna, probably indicating the existence of a same fauna that lived along the coasts of the seaway that flooded the southern half of the Potosí basin (Fiedler et al. 2003) by the end of the Cretaceous.

Conversely, the new locality of Tunasniyoj represents levels that are considered around 73 million years older than all the previously mentioned Upper Cretaceous localities, opening the chance to study a dinosaurian ichnofauna ignored up to now in the region.

\section{GeOLOGicAl SETting}

The Tunasniyoj tracksite is located in the Chuquisaca side of the Incapampa-Icla syncline. This forms part of a syncline system that exposes a Tertiary core surrounded by Cretaceous to Jurassic verticalized beds that outcrop in several Departments of Bolivia in the eastern part of the Andes. The bearing beds, thus, form welldeveloped walls of reddish sandstones, locally covered by basalt flows originated during the Early Cretaceous (Almeida et al. 1996). The track-bearing beds are part of the fluvial to aeolian La Puerta Formation, deposited in Late Jurassic to Early Cretaceous time (Almeida et al. 1996). As different units considered to have been deposited during the latest Jurassic to earliest Cretaceous from Brasil, Bolivia, Paraguay, Uruguay and Argentina show an aeolian signature, it is possible that the La Puerta Formation could be a distal extension of the Brazilian unit, known as the Botucatú desert (Scherer 2000).

\section{MATERIALS AND METHODS}

Tracks were exposed by clearing away sand, small rocks and debris. Measurements were taken directly from trackway impressions, following standard ichnological conventions (see Table I).

From the impressions, we obtained the following measurements (Thulborn 1990): pes length (maximum antero-posterior measurement) and pes width (maximum medio-lateral measurement), pace length (distance between corresponding points in two successive footprints), internal trackway width (distance between the inner edge of left and right footprints; negative values indicating track overlapping), external trackway width (distance between the outer edge of left and right footprints), and pace angulation (angle formed between line segments connecting the anteriormost point of consecutive pes tracks) (see Fig. 2D). Additionally, we considered the rotation of the track in respect to the midline of the trackway. Individual tracks and trackways were photographed and measured with steel tape measure and caliper. Figures were made with Adobe Photoshop CS3. 
TABLE I

Measurements of the Tunasniyoj tracks. (?) unknown. (-) not applicable.

\begin{tabular}{|c|c|c|c|c|c|c|c|c|}
\hline & & $\begin{array}{l}\text { Length } \\
(\mathrm{cm})\end{array}$ & $\begin{array}{l}\text { Width } \\
(\mathrm{cm})\end{array}$ & $\begin{array}{l}\text { Pace length } \\
\quad(\mathrm{cm})\end{array}$ & $\begin{array}{c}\text { Internal trackway } \\
\text { width }(\mathrm{cm})\end{array}$ & $\begin{array}{c}\text { External trackway } \\
\text { width }(\mathrm{cm})\end{array}$ & $\begin{array}{l}\text { Pace angulation } \\
\left({ }^{\circ}\right)\end{array}$ & $\begin{array}{c}\text { Rotation from } \\
\text { midline }\left({ }^{\circ}\right)\end{array}$ \\
\hline \multirow{4}{*}{$\begin{array}{c}\text { Ichnotaxon } \\
\text { A }\end{array}$} & $\begin{array}{l}\text { Adult } \\
\text { manus }\end{array}$ & 11 & 14 & 50 & 3 & 33 & 120 & $5-15$ \\
\hline & $\begin{array}{l}\text { Adult } \\
\text { pes }\end{array}$ & 35 & 25 & 50 & 3 & 60 & 120 & 0 \\
\hline & $\begin{array}{c}\text { Juvenile } \\
\text { manus }\end{array}$ & 3 & $5-6$ & 40 & 5 & 18 & 145 & 24 \\
\hline & $\begin{array}{c}\text { Juvenile } \\
\text { pes }\end{array}$ & 12 & 9 & 40 & 1 & 20 & 145 & -14 \\
\hline \multirow{2}{*}{$\begin{array}{c}\text { Ichnotaxon } \\
\text { B } \\
\end{array}$} & Manus & 21 & 30 & $?$ & $?$ & $?$ & $?$ & 13 \\
\hline & Pes & 25 & 35 & 122 & 48 & 103 & 100 & 0 \\
\hline \multirow{2}{*}{$\begin{array}{c}\text { Ichnotaxon } \\
\mathrm{C}\end{array}$} & Manus & 15 & 23.5 & 52.5 & 16.5 & 60 & $?$ & 16 \\
\hline & Pes & 18 & 35 & 52.5 & -25 & 45 & $?$ & 0 \\
\hline \multirow{2}{*}{$\begin{array}{c}\text { Ichnotaxon } \\
\text { D }\end{array}$} & Manus & - & - & - & - & - & - & - \\
\hline & Pes & 35 & 35 & $?$ & $?$ & $?$ & ? & $?$ \\
\hline
\end{tabular}

\section{RESULTS}

Five ichnotaxa, named as A, B, C, D, and E, were described in the area. They were later assigned to four different trackmakers, three of them quadrupedal and one bipedal.

Ichnotaxon A (Fig. 2A-D). It is the most abundant ichnotaxon and is represented by several trackways. They are not undertracks. They correspond to quadrupedal animals, presumably adults. The four digit pes impressions show a paraxonic arrangement and a probable syndactily between the imprints of digit I and II. The heel mark is separated from the rest of the footprint showing a transversal positive epichnial ridge in some impressions (Fig. 2B). The pes impression length is about $35 \mathrm{~cm}$, and its width is $25 \mathrm{~cm}$. A great number of prints was preserved as long and continuous trackways that reach $30 \mathrm{~m}$ in length (Fig. 3A), with an average pace angulation of $120^{\circ}$ for the footprints. Both pes and manus paces length is $50 \mathrm{~cm}$. Further, the average outer trackway width is $60 \mathrm{~cm}$, and the inner trackway width ranges from $0 \mathrm{~cm}$ to $5 \mathrm{~cm}$, thus corresponding to a narrow trackway. Manus imprints are tetradactyl, short and broad, with about $11 \mathrm{~cm}$ in length and $14 \mathrm{~cm}$ in width. The manus impressions are located anterior and medially to the pes impressions, and show a slight rotation relative to the midline, which ranges from $5^{\circ}$ to $15^{\circ}$. The angles formed by the digit imprints are homogeneous, having an average of $30^{\circ}$, depicting an arch of $120^{\circ}$.
Ichnotaxon B (Fig. 2E-G). These tracks were made by a quadrupedal animal and they are three times smaller than those of ichnotaxon A. The tetradactyl pes impression is symmetrical, with the imprints of the digits I, II and III directed forwards, and the IV laterally projected. The heel mark is well separated from the anterior part of the footprint by $3 \mathrm{~cm}$. Pes impression length is about $12 \mathrm{~cm}$, and the average width is $9 \mathrm{~cm}$. The longest trackways comprise 20 continuous steps (Fig. 3B), with an average pace angulation of $145^{\circ}$ for the footprints. The pes and manus imprints display an average pace length of $40 \mathrm{~cm}$, while an external/internal width ranges from $20 \mathrm{~cm}$ to $5 \mathrm{~cm}$, respectively.

The manus print has four digit impressions. It is short and broad, with a manus length of about $3 \mathrm{~cm}$ and range width from $5 \mathrm{~cm}$ to $6 \mathrm{~cm}$. Digit imprints are symmetrically arranged in a wide arch of $140^{\circ}$ to $160^{\circ}$. As in ichnotaxon $\mathrm{A}$, manus prints are located in front of footprints displaying an outward rotation from midline.

Ichnotaxon C (Fig. 4). This ichnotaxon C is mostly represented by large and continuous trackways with pes and manus impressions. However, most trackways are represented only by pes impressions that we consider overlapping manus prints. The tetradactyl pes impression is symmetrical, with rounded end digit imprints and forwardly projected. The pes track is wide and no heel is distinguished (Fig. 4B). Pes track is $25 \mathrm{~cm}$ long and $35 \mathrm{~cm}$ maximum wide. These specimens are repre- 

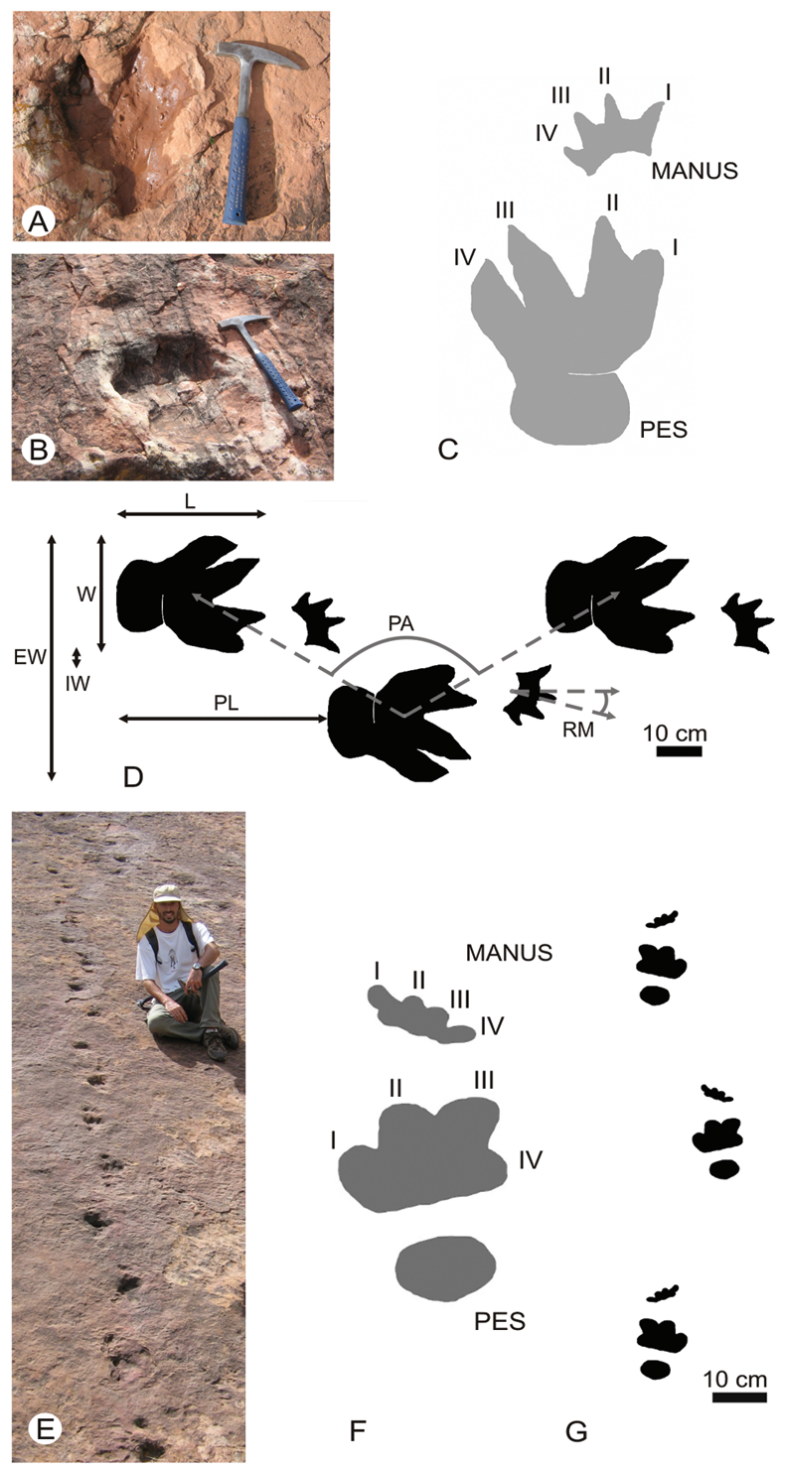

F
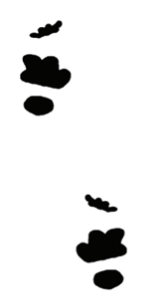

Fig. 2-Ichnotaxa A and B. Pes and manus of the Icnotaxon A (A, B, C), trackway scheme with distances preserved and principal measurements taken (D). Ichnotaxon B trackways (E), track and trackway scheme (F, G). Abbreviations: EW, external trackway width; IW, internal trackway width; L, length; PA, pace angulation; PL, pace length; RM, rotation from midline; W, width.

sented by four trackways about $15 \mathrm{~m}$ in length and with an average pace angulation of $100^{\circ}$. Pes impressions have a pace length of about $122 \mathrm{~cm}$. There is an evident change in width along the trackway as a consequence of a small change of direction of travel at midway. The maximum external trackway width, here interpreted as the normal pace width, is $103 \mathrm{~cm}$, and the internal width is $48 \mathrm{~cm}$. On the other hand, by the zone of change direction, the maximum width decreased to $71 \mathrm{~cm}$, and the internal width became $20 \mathrm{~cm}$ (negative value), overlapping the midline of the trackway.

Manus prints are only present in few specimens, but all of them are well preserved. Manus print is pentadactyl, short and kidney-shaped, with a deep posterior excavation. It is transversally long and the finger impressions depict a splayed arch. All digits imprints but $\mathrm{V}$ have evident claw marks. Digits imprints are symmetrically displayed, but some specimens show digit I opposed to the rest. The impressions of the digits IV and $\mathrm{V}$ are in syndactily.

Ichnotaxon D (Fig. 5A-B). This ichnotaxon, less frequent than ichnotaxa $A, B$, and $C$, is represented by some few trackways, with manus and pes impressions from a large quadrupedal animal.

The four-digited pes imprint is asymmetric with digit IV directed laterally, which is separated from the others. Digit I imprint, even smaller, is opposed (anteromedially directed) to digit IV imprint. Digits II and III imprints are projected forwards and partially fused at the base.

Footprint is wide and short, and no heel mark is present (Fig. 5A, B). The length of the pes is $18 \mathrm{~cm}$ and $35 \mathrm{~cm}$ in maximum width between digits I and IV. This taxon is represented only by a single partial trackway that includes two pes and manus couples. The pace of the pes tracks is about $52.5 \mathrm{~cm}$ in length. Manus print is pentadactyl, very short, and with very small digits impressions depicting a serrated anterior border. It shows an inwards rotation of $37^{\circ}$ from the midline. There is no evidence of claw marks. The first three digit impressions are medially oriented, with digit IV projected forwards and digit $\mathrm{V}$ directed anterolaterally.

Ichnotaxon E (Fig. 5C-E). This ichnotaxon includes isolated footprints that probably correspond to a bipedal animal. The pes track is tridactyl and symmetric. The impressions of the digits are divergent and display a clover-leaf shape, with narrow claw marks at least in digits II and III. The footprint is about $35 \mathrm{~cm}$ in length as well as in width. As isolated footprints, more locomotion and trackway data are needed. 


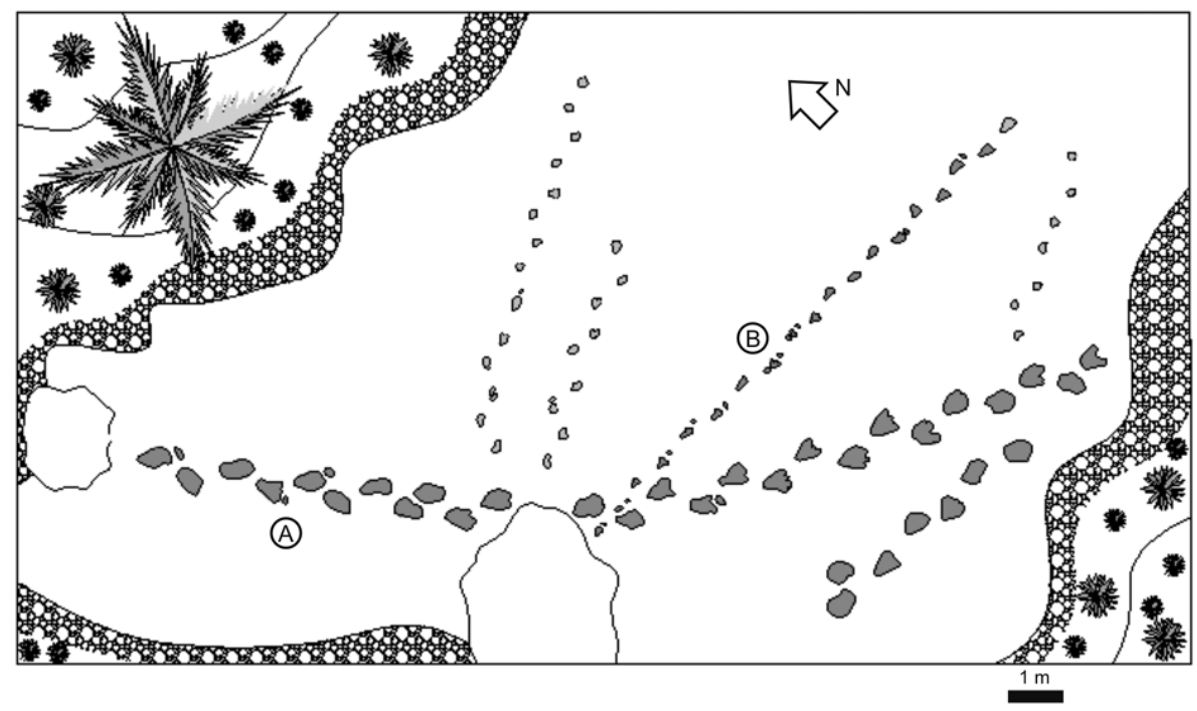

Fig. 3 - Trackway map of ichnotaxa A and B showing spatial relation between both ichnotaxa trackways.

\section{DISCUSSION}

\section{IDENTIFICATION OF THE TUNASNIYOJ TRACKMAKERS}

The establishment of unequivocal relationships between a fossil track and its possible producer is highly speculative, and assignations are, as much, tentative. However, the knowledge gathered after the study of the skeletal anatomy of several dinosaur groups allows a correlation between skeletal structure and track shape.

In this case of study, most of the tracks were produced by taxa that are poorly known or very debated in bibliography. Among them, stegosaurians are one of the most problematic. Most of the discussion on stegosaurian footprint assignment is based on time correlation and its osteological presence in the bearing locality. However, in South America, the only stegosaur remains are restricted to basal forms found in Barremian rocks of Patagonia (Bonaparte 1996). This opens the panorama to find stegosaurian tracks in any South American Early Cretaceous tracksite and perhaps in all Gondwanan, after the re-assignment of the material from the Early Jurassic of Australia originally described by Hill et al. (1966). The finding of the Late Jurassic stegosaur Kentrosaurus Hennig (1915) in Tendaguru, Tanzania, is in agreement with this hypothesis. After the poor South American stegosaurian remains, it is deduced that there existed a radiation of basal forms and, thus, is expected to find tetradactyl forms.
Five ichnotaxa are represented in the "Palmar de Tunasniyoj". Four of them were likely produced by non-ornithischian ornithopods, and one by a probable saurischian.

Ichnotaxa $\mathbf{A}$ and $\mathbf{B}$. The material from Bolivia includes a separation of the pes impressions in two symmetrical units: the digit imprints and the anterior part of the sole and the heel mark (Fig. 2B, E). Further, the impressions of the digits splayed in two divaricating axes, partially resembling the situation present in artiodactyls like cows and camels.

Besides the discussion of bipedal or quadrupedal gait in stegosaurs, which is irrelevant in animals that were anatomically capable to use both stances, one of the main concerns to consider the identity of ichnotaxa $\mathrm{A}$ and $\mathrm{B}$ is that their pedal tracks are not tridactyle, as diagnosed for Stegopodus and presumed for most purported stegosaur tracks (e.g., Gierlinski and Sabath 2008). Ichnotaxa A and B also differ from Stegopodus in the blunt and short toed pedal prints of the latter.

Considering Deltapodus tracks, which are also considered as tridactyles, some specimens show an inner bulging (Whyte and Romano 2001, Fig. 4) of the second toe that could actually correspond to the reduced digit I of ichnotaxon A. This is especially visible in D. brodricki (Whyte and Romano 2001, Fig. 4), which shows four evident impressions. Moreover, the tridactyle MNHM-1010 from Morrison Formation (Moss- 

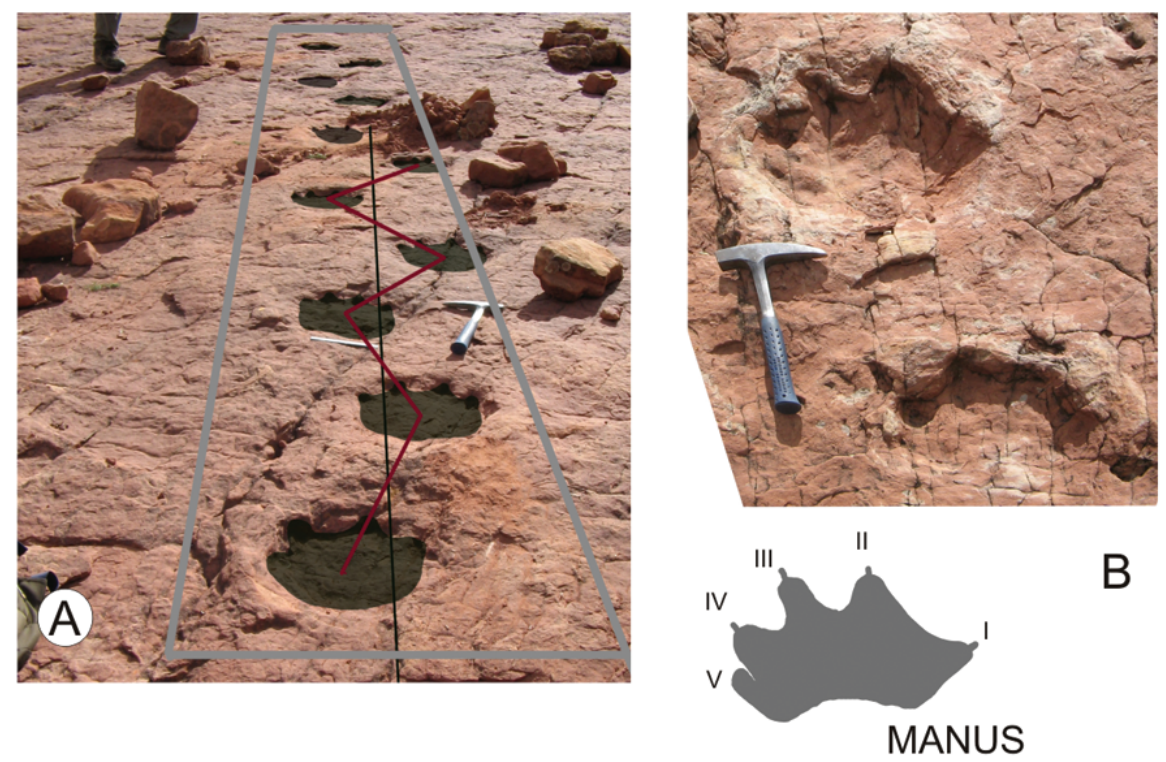

$10 \mathrm{~cm}$
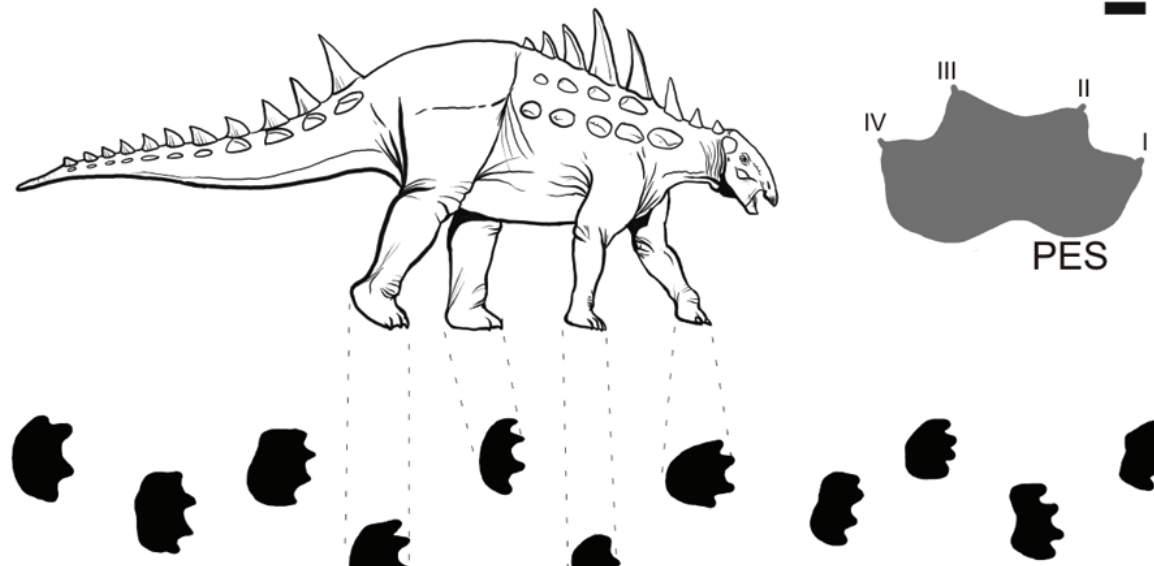

C
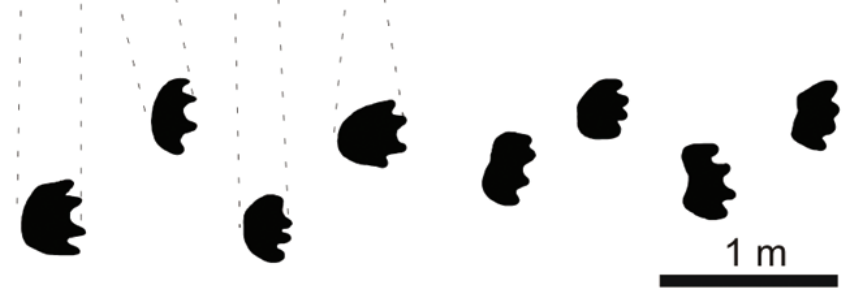

Fig. 4 - Ichnotaxon C. Trackway (A), isolated pes and manus of adult specimens in photograph (B up) and scheme (B down), detailed trackway scheme with distances preserved (C).

brucker et al. 2008), with an extremely wide inner digit, and the clearly tetradactyle footprints from the Early Jurassic of Morocco (Jenny and Jossen 1982, Type C) were already suggested to be related to stegosaur activity. Furthermore, the Australian tracks reported by Long (1998) show this more clearly, not having only an additional toe but also showing it in a position that seems to support sindactily between toes I and II (Scanlon 2006, Fig. 5D). Additionally, they share with the Tunasniyoj material a deep embayment between the II and III toes, though very asymmetrically distributed.
In this sense, an interesting fact is that pes in purported stegosaurs, differing from iguanodonts, is asymmetrical, with the proximal pad located posterolaterally. In both ichnotaxa A and B, the symmetry axis of the footprints is between digits II and III. If A and B were made by a basal stegosaur, it is logical that secondarily tridactyl forms that reduced the digit I could have shown an asymmetrical tridactily, different from that of iguanodonts. Although derived stegosaurians present only three digits in the pes, and several forms show even a trend to have only two pedal digits, as evident in both skeletons and 

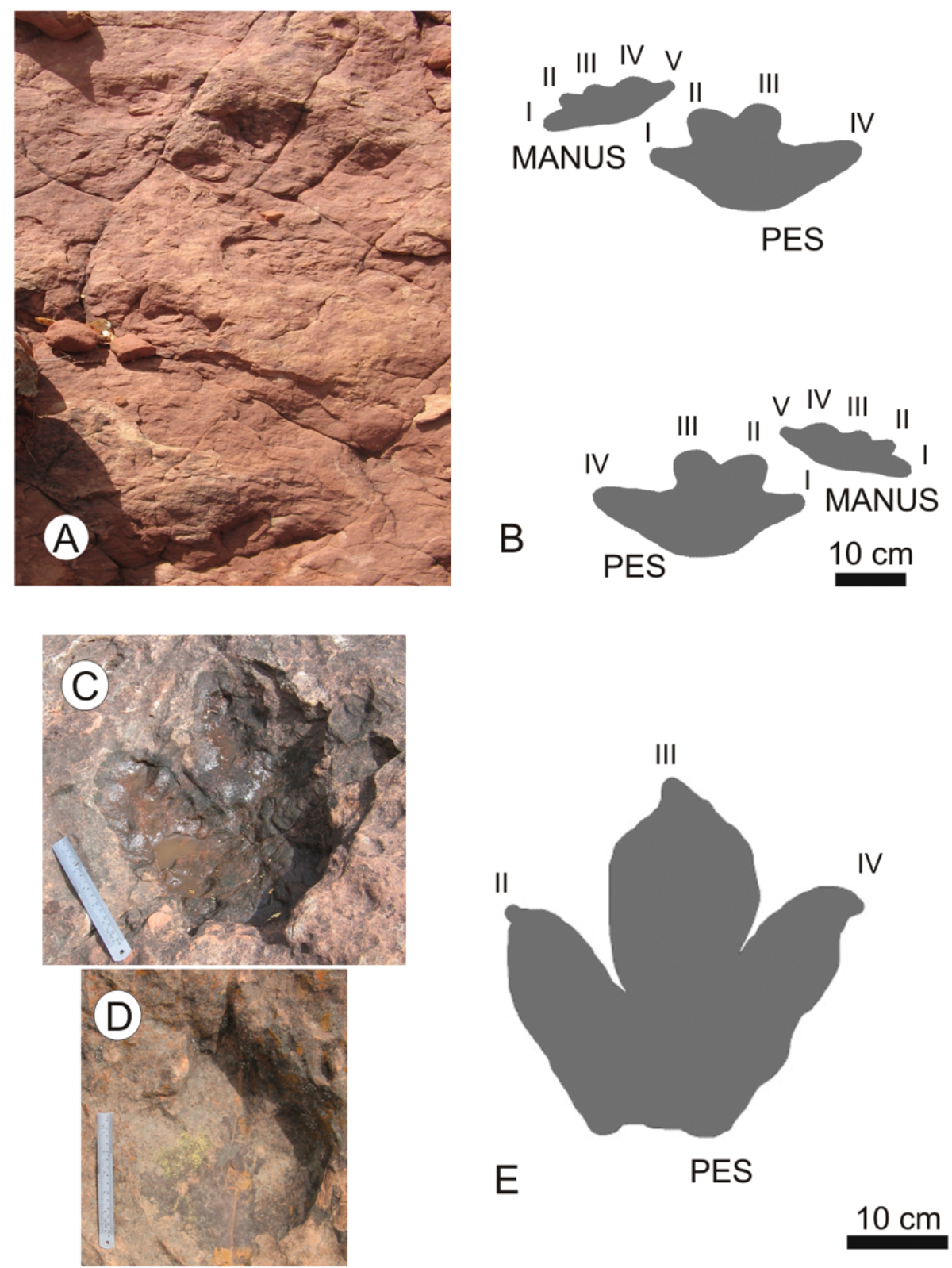

Fig. 5 - Ichnotaxon D. Trackway (A) and scheme with distances preserved (B). Ichnotaxon E. Track $(\mathrm{C}, \mathrm{D})$ and detailed scheme $(\mathrm{E})$.

trackways (Lockley and Hunt 1998), the available material shows that, by the Early Cretaceous, only basal forms were present in South America (Bonaparte 1996). Basal stegosaurians are considered to have four pedal digits with a reduced digit I, as also regarded for the long-toed form Tetrapodosaurus (Sternberg 1932) considered as produced by a basal ankylosaurian or even a ceratopsian (Gierlinski and Sabath 2008; but see McCrea et al. 2001, who compares it with the Sauropelta skeleton).
Conversely, Laurasian forms as those from Tereñes Cliffs, Spain (Lires et al. 2002, García-Ramos et al. 2004), with less asymmetrical pes, more crown-shaped and with digits more similar in length than those from Utah (Gierlinski and Sabath 2008) and Poland, are more derived, despite the older age. The material from Poland (Gierlinski and Sabath 2002), slightly longer than wide, with a reduction of digit IV when compared to digits II and III, shows a probable trend to didactyly, thus in- 
creasing the pedal diversity of the group.

The strong heel of ichnotaxa A and B, a feature frequently cited as present in stegosaurian tracks, turns the track much longer than wide. This strong heel is also present in the short-toed ichnogenus Navahopus (Baird 1980) or Apulosauripus (Nicosia et al. 1999), considered as produced by possible ankylosaurians, and Deltapodus (Whyte and Romano 1994) from the Saltwick Formation, considered as stegosaurian in origin (Whyte and Romano 2001, Fig. 3), and supported by additional stegosaurian skeletal remains from the Late Jurassic of Asturias (Spain) (Lires et al 2002, García-Ramos et al. 2004). Gierlinsky and Sabath (2008) have considered that Deltapodus bears a sauropod-like aspect. However, we agree more with the stegosaurian interpretation of Whyte and Romano (2001).

The manus imprints of Deltapodus are also similar to those coming from the Tunasniyoj locality, with a manus short, wide and describing an arch. However, several differences preclude assigning the Bolivian material to that genus (e.g., well-defined digits, outward rotation, and digit one in the same line of others in the Tunasniyoj material).

The manus of ichnotaxa A and B differs from the Australian material described by Long (1998) mainly in the higher heteropody and in the presence of four instead of five digits in the former.

In sum, we suggest that ichnotaxa A and B were produced by a basal stegosaur trackmaker, based both in an anatomical correlation plus the temporal framework. These tyreophoran dinosaurs, highly specialized heteropodal quadrupeds, show a short trunk relative to the length of their hindlimbs. Additionally, their short forelimbs produce a peculiar movement when walking; this is translated in the tracks as an orientation of the manus outwards. The manus imprint in ichnotaxon $\mathrm{A}$ is entaxonic and tetradactyl.

Ichnotaxon C. The comparison of this ichnotaxon also suggests a tyreophoran trackmaker. Four digited feet are well developed in basal tyreophoran forms comparable to Scelidosaurus (Norman 2001) and Polacanthus (Blows 1987) (Fig. 4C). Ichnotaxon $\mathrm{C}$ is very similar to the tetradactyl and rounded Tetrapodosaurus borealis, from British Columbia, Canada (Sternberg 1932). Although Tetrapodosaurus has manus print well docu- mented, this is not the case of ichnotaxon $\mathrm{C}$, in which footprints overlap manus prints in most trackways. In this way, a similar condition seems to be present in trackways attributed to ankylosaurs from the Late Cretaceous of Brazil (Huene 1931, Thulborn 1990). Tetrapodosaurus trackmakers were assigned as ankylosaurs or related (Thulborn 1990, Whyte and Romano 2001), or ceratopsians (Gierlinski and Sabath 2008). In the case of ichnotaxon $\mathrm{C}$, the anatomical correlation and temporal framework are consistent with a trackmaker assignment as a basal tyreophoran, perhaps related to the ankylosaur lineage. As this group spread very early along the Mesozoic world, it is expected that unspecialized basal tyreophorans lived in South America.

Ichnotaxon D. Besides represented by only few tracks, its distinct morphology allows its assignment to the Ankylosauria, which is already known from the younger strata of Cal Orck'o, Sucre (McCrea et al. 2001), in the El Molino Formation and in Toro Toro, Potosí, in the Toro Toro Formation or in the lower member of the El Molino (Gayet et al. 1991). The latter includes the holotype of Ligabueichnium bolivianum Leonardi 1984, considered both as a Ceratopsia or an Ankylosauria. Unfortunately, they are badly preserved for comparisons. Considering the age of the bearing rocks, these tracks actually represent the older evidence of these dinosaurs for the Southern Hemisphere, even older than the Early Cretaceous Minmi from Australia (Molnar 1980).

Ichnotaxon E. The only tracks assigned here to theropod dinosaurs, so abundant in other assemblages (e.g., Lockley et al. 2002, Leonardi 1994, Rubilar-Rogers et al. 2008), are those represented by ichnotaxon E. However, they are quite unusual for the group. The tracks are extremely wide, and digits are petal-shaped, resembling ornithopod tracks. Therefore, the main reason for its assignment to Theropoda is mainly based on the terminal sharp claw marks.

The presence of large theropod dinosaurs in Late Jurassic to Early Cretaceous beds suggests the presence of large basal tetanurans like carcharodontosaurids and spinosaurids, as well as basal ceratosaurians, already regarded for Early Cretaceous strata (Rauhut 2004). Furthermore, other large petal-shaped trackways were described for the early Late Cretaceous from Argentina as 
Limayichnus Calvo 1991, although assigned to huge ornithopods. Considering the evidence studied here, $\mathrm{Li}$ mayichnus could also be related to large tetanurans like carcharodontosaurids, which are already known for the site (i.e., Giganotosaurus carolinii Coria and Salgado 1995). The presence of these theropods in Tunasniyoj is in agreement with the Early Cretaceous age of the site (Apesteguía 2002, Leanza et al. 2004), and different from the latest Cretaceous tracks of the El Molino Formation.

\section{CONCLUSIONS}

The discovery of a new well-preserved tracksite in horizons 73 million years older than all those previously known in Bolivia opens the possibility to acknowledge the different forms that lived towards the JurassicCretaceous boundary and to explore how ichnofaunas evolved. As many researches demonstrated during the last years, several tetrapod lineages actually originated much earlier than expected, and long ghost lineages were proposed to explain their presences in Late Cretaceous outcrops, an aspect that highlights the importance of Late Jurassic-Early Cretaceous presences.

The presence of confirmed thyreophorans in Southern continents was proposed after the description of the Australian Early Cretaceous Broome Sandstone tracks (Hill et al. 1966) and later by osteological findings in South America (e.g., Bonaparte 1996, Coria and Salgado 2001), Africa (e.g., Hennig 1915) Antarctica (e.g., Gasparini et al. 1996), and New Zealand (e.g., Wiffen 1996).

The group is distinguishable in the tracksite record by their four to five short, hoof-like toes, different from the laterally reduced pattern seen in saurischians and ornithopods. Australian tracks show broad five-toed hands and narrower hind feet with three functional toes but up to four digits.

Other candidates for a similar kind of tracks, the neoceratopsians, are not considered as possible Gondwanan pre-Campanian inhabitors. Thus, the possible producers are reduced to scelidosaurs, early stegosaurs, or basal ankylosaurians. Despite stegosaurs were common in the Late Jurassic of Laurasia, basal forms have been reported for the Early Cretaceous of several places in the world. In the Southern hemisphere, stegosaur tracks have only been described from Australia (Long 1998). Their crescentic shape, five-fingered manus tracks and broad and notably heeled pes tracks are characteristic of this group.

Considering that the Australian tracks and those of Tunasniyoj share manus tracks with several (four to five) short and well-defined digits, no inward directed pollex claw, and pes tracks broad and square in outline, with a deep divarication in the case of the Bolivian material, they were probably produced by stegosaurs belonging to the same lineage, differing from the tridactyle forms from the Jurassic of North America, as those of Deltapodus.

Most of the track localities of South America are represented in rocks from the uppermost Cretaceous, and older track assemblages display a poor to moderate preservation, providing this discovery with both temporal and regional significance. The Tunasniyoj assemblage is the oldest dinosaur tracksite for Bolivia, and includes the oldest known evidence assigned to ankylosaurs and stegosaurs for South America.

\section{ACKNOWLEDGMENTS}

Authors would like to acknowledge the Tourism Direction represented by the Lic. Roxana Acosta of the Prefectura of Chuquisaca Dept. (Bolivia), and the Prefect, Ms. Savina Cuéllar Leaños that supported the Project "Investigación paleontológica en el Municipio de Icla, Chuquisaca, Bolivia”. Also to the Architect Omar Medina Ramírez, true organizer of this Project, and Mr. Eddy Alvarado Rocabado, driver and soul of the fieldtrip. Special thanks should be also extended to Mr. Primo Rivera Salazar and Eloy Mendez Cárdenas, founders of the trackways, Don Faustino Silva Soto, "agente cantonal" from the district IV of the Icla area, Don Pedro Vela Condori (H. Mayor of the Municipality of Icla) and Ing. José Calderón (President of the Municipal Counceil of Icla). We appreciate the help of D. Riff in the Portuguese translation of the abstract. We thank the four anonymous reviewers for their comments and suggestions which notably improved the manuscript. Finally, we acknowledge Dr. Alexander Kellner and Dr. Yukimitsu Tomida for their invitation to participate in the Gondwanan dinosaurs and associated fauna volume. 


\section{RESUMO}

Neste estudo é relatado um conjunto magnificamente preservado de pistas de dinossauros representados por cinco táxons distintos, situado próximo à Vila de Icla, 100 quilômetros a sudeste do Sucre, Bolívia. Preservados em arenitos eólicos avermelhados do limite Jurássico-Cretáceo. Quatro formas geradoras foram identificadas na área, sendo três quadrúpedes e um bípede, todos com as pegadas com cerca de $35 \mathrm{~cm}$ de comprimento. Um dos quadrúpedes (trilhas tipos A e B) é representado por pelo menos seis indivíduos em dois grupos de três, com adultos e juvenis juntos. Os outros dois quadrúpedes (trilhas tipos C e D) são geradores de quatro trilhas, e um gerador bípede (trilha E), é representado por uma trilha. Os quatro icnotáxons representados em "Palmar de Tunasniyoj", podem provisoriamente ser atribuídos aos seguintes geradores: Icnotáxon A e B são atribuídos a estegossauros basais. Icnotáxon $\mathrm{C}$ a um tireóforo basal, talvez relacionado à linhagem dos anquilossauros. Icnotáxon D aos Ankylosauria; e icnotáxon E a Theropoda. Este raro e belo conjunto de trilhas de dinossauros de Tunasniyoj, representa ainda a icnocenose mais antiga de dinossauros da Bolívia. Além disso, inclui a mais antiga evidência conhecida atribuída a anquilossauros e estegossauros para América do sul.

Palavras-chave: Bolívia, Chuquisaca, pegadas de dinossauros, icnologia.

\section{REFERENCES}

Almeida LF, Pérez Morales R, Carrasco Córdova R ANd PALENQUe DE LA Quintana GA. 1996. Mapas temáticos de Recursos minerales de Bolivia, Hoja Sucre. Serv Geol Bol Serie II-MTB-8B.

APESTEguía S. 2002. Successional structure in continental tetrapod faunas from Argentina along the Cretaceous. Bol $6^{\text {th }}$ Simp Cret Brazil-2 ${ }^{\text {nd }}$ Simp Cret Am Sur Abst, p. 135141.

Apesteguía S, de Valais S, Meyer CA, Ríos CorDERO G AND RAMIREZ OM. 2007. Reduced inner toe theropod trackways from El Molino Formation (Maastrichthian) at Toro Toro (Bolivia). Abstracts V Reun Arg de Icnol and III Reun de Icnol del Mercosur 47.

BAIRD D. 1980. A prosauropod dinosaur trackway from the Navajo Sandstone (Lower Jurassic) of Arizona. In: JACOBS LL (Ed), Aspects of Vertebrate History. Flagstaff: Museum of Northern Arizona Press, p. 219-230.

BLows WT. 1987. The armoured dinosaur Polacanthus foxi, from the Lower Cretaceous of the Isle of Wight. Palaeontology 30: 557-580.
BONAPARTE JF. 1996. Cretaceous Tetrapods of Argentina. In: PfeIl F AND ARratia G (Eds), Contributions of southern South America to Vertebrate Paleontology. Münchner Geowissenschaftliche Abhandlungen. Reihe A Geol und Paläont, p. 73-130.

BRANisA L. 1968. Hallazgo del amonite Neolobites en la Caliza Miraflores y de huellas de dinosaurios en la Formación El Molino y su significado para la determinación de la edad del "Grupo Puca". Bol Inst Boliv Petr 8: 16-28.

CALvo JO. 1991. Huellas de Dinosaurios en la Formación Río Limay (Albiano-Cenomaniano), Picún Leufú, provincia del Neuquén, Argentina (Ornithischia-Saurischia-Sauropoda-Theropoda). Ameghiniana 28: 241-258.

CORIA RA AND SALGADO L. 1995. A new giant carnivorous dinosaur from the Cretaceous of Patagonia. Nature 377: 224-226.

Coria RA AND SAlgado L. 2001. South American ankylosars. In: CARPENTER K (Ed), The armored dinosaurs, Indiana University Press, p. 159-168.

Fiedler K, Mertmannn D and Jacobshagen V. 2003. Cretaceous marine ingressions in the southern Potosi Basin of southern Bolivia: tectonic and eustatic control. Rev YPFB 21: 157-164.

García-Ramos JC, PiÑUela L AND LiRes J. 2004. Guía del Jurásico de Asturias. Ed. Zinco Comunicación, Gijón, $118 \mathrm{p}$.

Gasparini Z, Pereda-Suberbiola X And Molnar RE. 1996. New data on the ankylosaurian dinosaur from the late Cretaceous of the Antarctic Peninsula. Mem Queensl Mus 39: 583-594.

Gayet M, Marshall LG and Sempere T. 1991. The Mesozoic and Paleocene vertebrates of Bolivia and their stratigraphic context: a review. In: SUÁREZ-SORUCO R (Ed), Fósiles y facies de Bolivia-Vol. 1 Vertebrados. Revista Técnica de YPFB 12(3-4): 393-433.

Gierlinski GD AND SABATH K. 2002. A probable stegosaurian track from the Late Jurassic of Poland. Acta Pal Pol 47(3): 561-564.

Gierlinski GD AND SABATH K. 2008. Stegosaurian footprints from the Morrison Formation of Utah and their implications for interpreting other ornithischian tracks. Oryctos 8: 29-46.

HeNNIG E. 1915. Kentrosaurus aethiopicus, der Stegosauride des Tendaguru. Sitzungsber Ges Naturforsch, p. 219-247.

Hill D, Playford G AND Woods JT. 1966. Jurassic Fossils of Queensland. Queensland Paleontographical Society, Brisbane, $210 \mathrm{p}$.

HUENE F. 1931. Verschiedene mesozoische Wirbeltierreste aus Südamerika. Neu Jahr Min, Geo und Pal, Abh 66: 181-198. 
JENNY J AND Jossen JA. 1982. Découverte d'empreintes de pas de dinosauriens dans le Jurassique inférieur (Pliensbachien) du Haut Atlas Central (Maroc) du Haut Atlas Central. Comp Rend des Sean de l'Acad des Scien de Paris, Ser II 294: 223-226.

Leanza HA, Apesteguía S, Novas FE And de LA FUENTE MS. 2004. Cretaceous terrestrial beds from the Neuquén basin (Argentina) and their tetrapod assemblages. Cret Res 25(1): 1-96.

LEONARDi G. 1981. As localidades com rastros fósseis de tetrápodes na América Latina. Anais $2^{\circ}$ Congr Latin-am Paleont 2: 929-940.

LEONARDI G. 1984. Le impronte fossili di dinosauri. In: Sulle ormi del dinosauri. Erizzo Publishers, p. 162-186.

LEONARDI G. 1994. Annotated atlas of South America tetrapods footprints (Devonian to Holocene). Comp de Pesq de Rec Min, Brasil, p. 39-41.

Lires J, Garcia-Ramos JC And Piñuela L. 2002. Icnitas de estegosaurios en los del Jurasico Superior de Asturias. In: PÉrez-Lorente F (Ed), Dinosaurios y Otros Reptiles Mesozoicos de España. Logroño: Resúmenes de las comunicaciones, ponencias y paneles, p. 30-31.

Lockley M, Schulp AS, Meyer CA, LeOnARdi G AND MAMANI KD. 2002. Titanosaurid trackways from the Upper Cretaceous of Bolivia: evidence for large manus, wide-gauge locomotion and gregarious behaviour. Cret Res 23: 383-400.

LOCKLEY MG AND HUNT AP. 1998. A probable stegosaur tracks from the Morrison Formation of Utah. In: CARPENTER K, Chure D AND KirKLAND J (Eds), The Upper Jurassic Morrison Formation: an interdisciplinary study. Mod Geol 23: 331-342.

LONG JA. 1998. Dinosaurs of Australia and New Zealand and Other Animals of the Mesozoic Era, Harvard University Press, Cambridge, $188 \mathrm{p}$.

McCrea RT, Lockley MG AND Meyer CA. 2001. Global distribution of purported track occurrences. In: CARPENTER K (Ed), The armored dinosaurs. Bloomington and Indianapolis: Indiana University Press, p. 413454.

MOLNAR RE. 1980. An ankylosaur (Ornithischia: Reptilia) from the Lower Cretaceous of southern Queensland. Mem Queens Mus 20: 65-75.

Moreno K And Pino M. 2002. Huellas de dinosaurios en la Formación Baños del Flaco (Titoniano-Jurásico Superior), VI Región, Chile: paleoetología y paleoambiente. Rev Geol Chile 29: 191-206.

Mossbrucker M, Lockley MG, Gierlinski G AND HUPS K. 2008. Probable stegosaur tracks from the Juras- sic Morrison Formation, Colorado and Utah. Din Rid Ann Rep 20: 26-29.

Nicosia U, Marino M, Mariotti N, Muraro C, Panigutti S, Petti FM and SAcchi E. 1999. The Late Cretaceous dinosaur tracksite near Altamura (Bari, southern Italy). Geol Rom 35: 237-247.

Norman D. 2001. Scelidosaurus, the earliest complete dinosaur. In: CARPENTER K (Ed), The armored dinosaurs. Bloomington and Indianapolis: Indiana University Press, p. 3-24.

RAUHUT OWM. 2004. Provenance and anatomy of Genyodectes serus, a large-toothed ceratosaur (Dinosauria: Theropoda) from Patagonia. J Vert Paleont 24: 894-902.

Ríos Cordero G. 2005. Contribución al Estudio de Dinosaurios en Bolivia. Informe de la expedición Toro Toro. 2004. Identificación de icnitas de dinosaurios del Parque Nacional Toro Toro, Provincia Charcas, Potosí. Pub del Club Paleont Boliv "FosilBol", 20 p.

Rubilar-Rogers D, Moreno K AND Blanco N. 2000. Grandes huellas de ornitópodos en la Formación Chacarilla: icnofacies indicadoras del Cretácico Inferior. IX Congreso Geológico Chileno. Servicio Nacional de Geología y Minería, Puerto Varas, Chile, 4 p.

Rubilar-Rogers D, Moreno K, Blanco N AND CALVO JO. 2008. Theropod dinosaur trackways from the Lower Cretaceous of the Chacarilla Formation, Chile. Rev Geol de Chile 35: 175-184.

SCANLON JD. 2006. Dinosaurs and other Mesozoic reptiles of Australasia. In: MERRICK JR, ARCHER M, HiCKEY G AND LEE M (Eds), Evolution and Biogeography of Australasian Vertebrates. AuSciPub, Sydney, p. 265-290.

SCHERER CMS. 2000. Eolian dunes of the Botucatu Formation (Cretaceous) in southernmost Brazil. Sed Geol 137: 63-84.

Sternberg CM. 1932. Dinosaur tracks from Peace River, British Columbia. Natl Museum Can Bull 68: 59-85.

ThUlborn T. 1990. Dinosaur tracks. Chapman and Hall, London, $410 \mathrm{p}$.

Whyte MA And Romano M. 1994. Probable sauropod footprints from the Middle Jurassic of Yorkshire, England. Gaia 10: 15-26.

Whyte MA And Romano M. 2001. Probable stegosaurian dinosaur tracks from the Saltwick Formation (Middle Jurassic) of Yorkshire, England. Proc Geol Assoc 112: $45-54$.

WIFFEN J. 1996. Dinosaurian palaeobiology: a New Zealand perspective. Mem Queensl Mus 39: 725-731. 